\title{
STUDI BIBLIKA DAN TEOLOGIS SURAT 2 PETRUS PASAL 3
}

\author{
Eliezer Lewis \\ Sekolah Tinggi Theologia Pontianak \\ eliezerlewis@yahoo.co.id
}

\begin{abstract}
Abstrak
Pengajaran yang benar tentang Kedatangan Kristus yang kedua kali sangat penting agar umat Allah tetap setia menanti kedatangan Kristus yang kedua kali. Kemunculan guru-guru palsu yang memberikan pengajaran yang tidak benar yang dialami oleh gereja mula-mula, menjadi pembelajaran bagi gereja masa kini. Ajaran guru-guru palsu berkaitan dengan adanya penolakan terhadap firman Allah, penolakan terhadap keilahian Kristus, dan penolakan terhadap kedatangan Kristus yang kedua kalinya. Secara biblika, Surat 2 Petrus 3 mengajarkan tentang penciptaan dan peristiwa air bah. Secara teologis surat ini menekankan tentang Kedatangan Kristus yang kedua kali, langit baru dan bumi baru, keselamatan untuk hidup yang kekal dan Alkitab sebagai firman Allah yang berotoritas.
\end{abstract}

Kata-kata kunci: guru-guru palsu, Kedatangan Kristus kedua kali, penciptaan, pengajaran Kristen

Correct teaching concerning the Second Coming of Christ is essential so that the Church is faithful in waiting for Jesus Christ's return. The emergence of false teachers which was experienced by the early church serves as a lesson for the contemporary church. The teaching of the false teachers is related to rejection of the Word of God, the rejection of the divinity of Christ, and the rejection of theteaching about the Second Coming of Christ. From a biblical point of view, 2 Peter 3 teaches about creation and the flood. Theologically, this letter emphasizes the Second Coming of Christ, a new heaven and earth, salvation that leads to eternal life, and the Bible as the authoritative Word of God.

Keywords: false teachers, the Second Coming of Christ, creation, Christian teaching

\section{Pendahuluan}

Janji kedatangan Kristus dan peringatan Tuhan kepada orang percaya mengenai guru palsu dan ajarannya dalam 2 Petrus 3 menyebutkan sekelompok bidat Kristen yang disebut guru-guru palsu. Golongan tersebut sebenarnya adalah Gnostik. Ajaran yang melahirkan paham gnoticisme yaitu, suatu bidat Kristen di abad 
pertama sampai ke empat yang percaya dualisme Allah-manusia, rohani-jasmani, dan menolak Yesus sebagai Allah, oknum kedua. ${ }^{1}$

Ajaran gnoticisme kuno itu tampak dalam dua bentuk kontradiktif, yaitu pengendalian yang sangat ketat terhadap hawa nafsu dan kebebasan yang tak terbatas. Masalah yang ditentang oleh Petrus adalah bentuk yang kedua, dan salah satu ajaran para guru palsu adalah penolakan mengenai kedatangan Kristus dengan menyatakan: "Dimanakah janji kedatangan-Nya itu? Sebab segala sesuatu tetap seperti semula, pada waktu dunia diciptakan" (2 Petrus 3:4). Bentuk pernyataan di atas mengungkapkan mengenai keraguan dan penolakan terhadap janji kedatangan Kristus kembali.

Rasul Petrus memperingatkan jemaat Tuhan Yesus yang disebutkan berada di Pontus, Galatia, Kapadokia Asia Kecil dan Bitinia (1 Petrus 1:1) dan kepada semua orang yang percaya kepada Yesus (band. 2 Petrus 2:1) supaya cerdas menghadapi penyesatpenyesat sehingga tetap hidup berkenan kepada Allah.

Kenyataan yang dihadapi oleh Rasul Petrus, hingga sekarang dan akan terus berlanjut. Enoch menegaskan dalam tulisannya bahwa:

“...kesalahan besar para cendekiawan, apakah ahli astronomi, geologi, ilmu fisika, ilmu kimia, ataupun biologi, yang menolak catatan Kejadian ialah uniformitarianisme, yaitu keyakinan bahwa sebab-sebab fisis serta akibat-akibatnya dianggap selalu sama dan seragam pada segala masa seperti yang kita lihat sekarang."

Penyelidikan ini akan memaparkan inti sari ajaran guru palsu dan janji tentang kedatangan Kristus kedua kali adalah bagian dari penggenapan seluruh nubuatan menyangkut peristiwa akhir zaman. Berakhirnya langit dan bumi yang baru. W. Stanley Heath, seorang pakar dalam bidang sains dan teknologi mengemukakan dalam bukunya, Tafsiran Kejadian 1-11, mengenai bukti ilmiah yang menunjukkan bahwa bumi akan keluar dari peredarannya dan akan terjatuh ke matahari. ${ }^{3}$ Pandangan tersebut cenderung mengarah pada penjelasan Alkitab, bahwa bumi ini akan dihanguskan oleh api dan hilang lenyap (band. 2 Petrus 3:10). Akan tetapi hal ini membutuhkan penyelidikan yang lebih lanjut untuk menjawab pertanyaan apakah benar bumi akan dihanguskan dengan api?

\footnotetext{
${ }^{1}$ Lihat Colin Brown, Filsafat dan Iman Kristen (Jakarta: Lembaga Reformed Injili Indonesia, 1994).

${ }^{2}$ Hannington Enoch, Evolusi atau Penciptaan (Bandung: Kalam Hidup, 1996), 29.

${ }^{3}$ W. Stanley Heath, Tafsir Kitab Kejadian 1-1l (Yogyakarta: Penerbit ANDI, 1999), 37.
} 
Urgensi penyelidikan ini dilandaskan pada beberapa alasan berikut: Pertama, kedatangan Kristus yang kedua kali adalah nubuatan yang akan digenapi. Janji tersebut akan dijelaskan dalam beberapa ayat berikut: Matius 24-25; Yohanes 14; Kisah Para Rasul 1:11; 2 Petrus 3:10-13; dan Wahyu 21. Kedua, sebagai penjelasan korektif bahwa fakta sejarah dan perubahan yang dilaporkan Alkitab dalam konteks 2 Petrus 3 tak dapat diabaikan, penyelidikan ini mengemukakan janji Tuhan akan digenapi dan orang percaya termotivasi untuk hidup dalam iman, pengharapan dan kasih.

\section{Dasar Pemikiran}

1. Surat 2 Petrus 3:9, Tuhan tidak lalai menepati janji-Nya.

2. Injil Matius 24-25, nubuatan tentang kedatangan Kristus kedua kali.

3. Injil Yohanes 14:1-3, Yesus berjanji akan datang kembali menjemput orang percaya.

4. Kisah Para Rasul 1:ll, Yesus akan datang kembali dengan cara yang sama seperti kenaikan-Nya ke surga.

5. Wahyu 21-22, nubuatan tentang kedatangan Kristus kedua kali dan kesudahan segala sesuatu.

\section{Tinjauan Mengenai Guru Palsu} Identitas Guru Palsu

a. Sikap Pemberontak

Guru palsu memiliki sikap hidup yang tidak kudus, tetapi amoral seperti di Sodom dan Gomora (2 Petrus 2:10-12). Ciri khasnya adalah membenci segala hal yang membatasi segala bentuk kekuasaan yang menghalangi untuk berbuat kejahatan.

Istilah "berani" pada ayat 11 menyatakan sikap peduli terhadap orang lain, bahkan terhadap bahaya bagi dirinya sendiri. Sedangkan kata "angkuh" menunjukkan sikap mementingkan diri sendiri yang didorong oleh kehendak untuk memuaskan keinginan-keinginan sendiri. Dengan keberanian dan keangkuhan menebar pemberontakan baik terhadap dirinya maupun terhadap para pengikutnya serta penolakan pemerintahan Kristus.

b. Bertingkah laku seperti Binatang Liar

Petrus mendeskripsikan mengenai guru-guru palsu berhubungan dengan kegiatan dan tingkah lakunya sama dengan hewan yang tidak berakal, dan berakhir seperti binatang liar" (2 Petrus 2:12). Istilah 
"binatang liar" diterjemahkan dari kata Yunani phusikos dan dalam bahasa Inggris belonging to nature. ${ }^{4}$

Bahwa nasib buruk akan menimpa para penyesat sebagai akibat dari kejahatan, berfoya-foya, mabuk oleh hawa nafsu, dan serakah (2 Petrus 2:13-14). Rasul Petrus menjelaskan secara detail, agar Jemaat dapat mendeteksi secara dini dan mengenal kegiatan mereka, bahwa guru palsu tidak pernah berhenti berbuat dosa dengan cara apapun demi kepuasan dan kepentingan diri sendiri (band. ayat 15-16).

c. Menuju Kebinasaan

Rasul Petrus menguraikan tentang kebinasaan atau kehancuran guru-guru palsu dalam 2 Petrus 2:17-22. Pendekatan tentang proses kebinasaan diuraikan mulai ayat 12, "Tetapi mereka itu sama dengan hewan yang tidak berakal, sama dengan hewan yang hanya dilahirkan untuk ditangkap dan dimusnahkan." Dalam bahasa Yunani kalimat ini dijelaskan: "hôs aloga zôa gegennêmena phusika eis alôsin kai phthoran." Kemudian dilanjutkan dalam ayat 12b, "mereka menghujat apa yang mereka tidak ketahui, mereka sendiri akan binasa seperti bianatang liar."

\section{Intisari Ajaran Guru-guru Palsu}

a. Penolakan terhadap firman Allah

Di dalam tulisan 2 Petrus pasal 3 ini, diawali dengan peringatan yang menjelaskan bahwa situasi sekarang di akhir zaman ini akan tampil para pengejek yang hidup menuruti hawa nafsunya keadaan yang digambarkan adalah ketidakpedulian terhadap perubahanperubahan dunia yang ada di sekelilingnya.

Petrus menggunakan fakta "pada waktu dunia diciptakan" (2 Petrus 3:4), yang ditegaskan dalam ayat 5 dengan frasa "oleh firman Allah langit telah ada sejak dahulu, dan juga bumi..." merupakan penegasan penciptaan. Dalam proses sejarah telah mengalami perubahan sebagai akibat dosa melalui air bah dan hingga sekarang melalui berbagai fakta historis dari keadaan yang dihadapi kini. Dijelaskan dalam lanjutan ayat 6, yaitu: “...dan bahwa oleh air itu, bumi yang dahulu telah binasa, dimusnahkan oleh air bah.

b. Penolakan ke-Tuhan-an Yesus

Surat 2 Petrus 3:4 menegaskan mengenai penolakan akan kedatangan Kristus sebagai implikasi dari keyakinan. Implikasi ini terlihat dalam 2 Petrus 2:lb: "Mereka akan memasukkan pengajaran-

\footnotetext{
${ }^{4}$ Gangel, Kenneth O. "2 Peter" In The Bible Knowledge Commentary: New Testament. Edited by John F. Walvoord and Roy B. Zuck (Wheaton: Scripture Press Publications, Victor Books, 1984), 872.
} 
pengajaran sesat yang membinasakan bahkan mereka akan menyangkal penguasa yang telah menebus mereka..." Harus menjadi Raja, pemimpin, dan penguasa dalam hidup orang percaya. Istilah Tuhan dipakai dalam Perjanjian Baru berulang kali untuk menunjuk kepada ke-Allah-an Kristus dan Kemahakuasan-Nya yang menjadi tema penting dalam keyakinan iman Kristus abad pertama (band. Kis. 2:36, Roma 10:9-10, Filipi 2:5-11, 1 Kor. 12:3). Salah satu ajaran sesat adalah menolak istilah penguasa menunjuk kepada padanan istilah "Tuhan" atau Kristus yang ke-Tuhan-an Kristus. Menolak pribadi Kristus sejak inkarnasi sampai kebangkitan dan kedatangan-Nya.

c. Penolakan Janji Kedatangan Kristus yang Kedua kali

Kedatangan Kristus kedua kali merupakan salah satu puncak dari janji Allah. Implikasi bahwa Kristus akan datang memacu iman orang percaya untuk tetap hidup dalam pengharapan. Tetap giat memberitakan Injil, selain itu pemahaman kepada Kristus dan jabatan-Nya sebagai Nabi, Imam dan Raja harus dilihat dari kebenaran kedatangan Kristus yang kedua kalinya. Doktrin ini meneguhkan kepada keyakinan keselamatan sebagai tujuan akhir.

Pengajaran sesat menyatakan bahwa Yesus tidak akan datang (2 Petrus 3:3-4). Dalam sebuah pertanyaan "Di manakah janji tentang kedatangan-Nya?" Pernyataan ini menggambarkan kenyataan penolakan. Target ajaran supaya orang percaya tidak hidup dalam kekudusan dan penyembahan kepada Tuhan. Tetapi berfoya-foya menikmati kesenangan duniawi. Keterangan Alkitab tentang doktrin kedatangan Kristus kedua kali merupakan nubuatan Alkitab yang menempati presentase yang cukup, baik Perjanjian Lama maupun Perjanjian Baru. Henry C. Thiessen, menyatakan bahwa:

Perjanjian Baru menyebut doktrin kedatangan Kristus kedua kali lebih dari tiga ratus kali. Bahkan ada gerakan pasal-pasal yang seluruhnya dipakai untuk memberitahukan kedatangan Kristus yang kedua kali ini (Matius 24, 25; Markus 13; Lukas 21; band. 1 Korintus 15). Bahkan ada kitab-kitab yang secara khusus ditulis untuk membahas pokok ini (1 Tesalonika, 2 Tesalonika dan Kitab Wahyu). Jelaskan bahwa doktrin ini dianggap sama pentingnya dengan doktrin-doktrin utama lainnya dari iman Kristen. ${ }^{5}$

\section{Argumentasi Biblika dan Teologi}

\section{Pendekatan Biblika}

\section{Penciptaan}

\footnotetext{
526.

${ }^{5}$ Henry C Thiessen, Teologi Sistematika (Malang: Penerbit Gandum Mas, 1993),
} 
Petrus menyatakan bahwa Allah telah menciptakan langit dan bumi melalui firman-Nya, 2 Petrus 3:5-7 (band. Mzm. 33:6, 9). Bahwa "Oleh firman Allah langit telah ada sejak dahulu, dan juga bumi yang berasal dari air dan oleh air..." Tetapi oleh firman itu juga langit dan bumi yang sekarang terpelihara dari api dan disimpan untuk penghakiman dan kebinasaan..." (2 Petrus 3:5,7). Kejadian pasal 1 menguraikan tentang penciptaan dengan memberi penekanan cara Allah bertindak dalam karya penciptaan-Nya.

Istilah bahasa Ibrani, kata "menciptakan" diterjemahkan dari kata bara $^{6}$ yang adalah bentuk kata kerja stem qal perfect, aktif dari orang ketiga maskulin. Kemudian diikuti oleh subjek Allah, Elohim. Karena memang istilah bara dipakai hanya untuk tindakan yang berkaitan dengan Allah dalam mengadakan sesuatu yang tidak ada menjadi ada (creatio ex nihilo). Kata ini sejajar dalam penggunaan Yunani Perjanjian Baru untuk istilah klizo yang bermakna menciptakan yang diindikasikan bahwa Allah adalah Tuhan yang berdaulat. Dari struktur tata bahasa jelas bahwa subjek pelaku adalah Allah (Elohim). Istilah yang berarti "yang kuat", kekuasaan tertinggi, pemimpin yang perkasa dan ke-Allah-an yang tertinggi. Diikuti kata kerja bara (menciptakan). Dalam bentuk zaman hal ini bermakna keagungan dalam karya dan tindakan yang luar biasa. ${ }^{7}$

Karena itu, penekanan argumentasi penciptaan sebagai keyakinan iman Kristen bertitik tolak dari penyataan pertama dalam Alkitab. Hendrikus Berkhof dalam bukunya, Christian Faith An Introduction to the Study of Faith, menyatakan bahwa tiga statement yang selalu harus dipikirkan orang Kristen, supaya tetap memiliki keteguhan iman menghadapi pengajaran sesat, yaitu: (l) pengakuan akan Allah sebagai penciptaan dengan kekuatan ilahi-Nya; (2) bahwa Allah menciptakan dunia ini melalui firman Allah; dan (3) bahwa Dia menciptakan dari yang tidak ada menjadi ada. ${ }^{8}$

Sidlow J. Baxter menegaskan dalam buku Menggali Isi Alkitab l, Kejadian-Ester, bahwa pernyataan Alkitab menggali Kejadian pasal 1:1 "Pada mulanya Allah menciptakan merupakan bukti yang kuat untuk

${ }^{6}$ Dalam istilah Ibrani, beberapa istilah yang diterjemahkan untuk kata menciptakan, seperti asa, yasar tapi kata bara digunakan khusus hanya untuk tindakan dan aktivitas ilahi melalui kuasa-Nya yang tak terbatas dalam melakukan segala sesuatu dari yang tidak ada menjadi ada. Lihat Sunis Stanislaus, Harmoni Kehidupan (Yogyakarta: Kanisius 2008), 15.

${ }^{7}$ Penjelasan diuraikan oleh H. D. M. Spence dan Joseph S. Exell, The Pulpit Bible Commentary Vol. 1 Geresis-Exodus (Peabody, Massachusetts: Hendrickson Publishers, 1996), 2-3.

${ }^{8}$ Hendrikus Berkhof, Christian Faith, An Introduction to The Study of The Faith (Michigan: Wm. B. Eerdmans Publishing Company, 1975), 153. 
menyangkal segala bentuk dan aspek pengajaran yang sesat yang berpangkal pada paham Gnostik." Karena hasil karya Allah dalam ciptaan-Nya. Dengan demikian, senada dengan pernyataan Petrus bahwa Allah telah menciptakan langit dan bumi dan telah dimusnahkan oleh air bah, tetapi juga langit dan bumi yang sekarang terpelihara disimpan untuk dimusnahkan (2 Petrus 3:5-7).

Sebagaimana karya Allah dalam penciptaan-Nya Dia bertindak melalui firman-Nya, demikian juga gambaran tentang kehancuran atau kebinasaan dunia (langit dan bumi) yang telah diciptakan Allah dan rusak oleh akibat dosa dijelaskan dalam 2 Petrus 3:5-7 sebagai berikut: "...bahwa oleh firman Allah langit telah ada sejak dahulu, dan juga bumi... tetapi oleh firman Allah itu juga langit dan bumi yang sekarang terpelihara dari api dan disimpan untuk hari penghakiman dan kebiasaan orang-orang fasik." Dalam bagian ini Petrus merekonstruksi sejarah masa lampau sejak penciptaan, air bah bahkan sampai masa depan yang ada di dalam pengawasan dan pengaturan Allah.

Istilah kontras ayat 7 "tetapi" menunjuk pada keadaan yang sama pada ayat 5 mengenai Allah Sang pencipta bertindak oleh firman-Nya yang sama (to auto logo-by the same word). Jadi Allah yang sama yang telah menciptakan langit dan bumi yang semua oleh firman-Nya juga mengakhiri segala sesuatu dengan kuasanya yang ajaib oleh firmanNya. Pada prinsipnya bahwa kehancuran akan kebinasaan sekali lagi dunia ini akan dilakukan oleh firman Allah untuk mengatakan penghakiman dan memberi pengharapan akhir.

Frasa "oleh firman Allah" $(3: 5,7)$ menunjuk kepada kekuatan kuasa-Nya dalam mengadakan sesuatu berdasarkan kedaulatan-Nya. Pernyataan "oleh Allah" to tou theou logo-by the word of God. Klausa ini memuat makna implikasi yang bereferensikan penciptaan langit dan bumi dalam Kejadian 1:1. Jadi "Creation by the Word of God" adalah merupakan ide atau gagasan umum dalam Perjanjian Lama dan Perjanjian Baru (Kej. 1:3-30; Mzm. 33:6,9; 148:5; Ezra 6:38,43; Ibrani 11:3) bahkan dalam kitab-kitab tradisi Yahudi. Para penulis Alkitab menegaskan mengenai bagaimana Allah akan menghancurkannya. Hal ini juga merupakan peneguhan atas kesaksian Allah dalam firmanNya (Mzm. 93:5), sehingga Allah Sang Pencipta langit dan bumi dan pemelihara berlaku sepanjang masa. Hal ini tidak seperti pernyataan para guru palsu, bahwa Allah telah merupakan hasil karya-Nya (band. 2 Ptr. 3:4).

\footnotetext{
${ }^{9}$ Uraian Baxter menyatakan bahwa penyataan dalam Kejadian 1:1 merupakan sangkalan terhadap ateisme, politeisme, fatalisme, evaluasi, pantheisme dan materialisme.
} 
Penggunaan istilah kosmos (bahasa Yunani) menunjuk kepada totalitas habitat hasil ciptaan yang merupakan arena kegiatan Allah dalam bertindak untuk menyatakan tujuan-Nya (band. Yoh 1:9, 3:16). Penjelasan ayat 7 lebih merupakan suatu gambaran tentang keadaan masa depan dengan kasus yang sama pada masa lampau mengenai kehancuran atau kebinasaan dunia. Selanjutnya, klausal "langit telah dan sejak dahulu dan juga bumi" ho tote kosmos - "the word of the time". (3:5-6), menunjuk kepada eksistensi seluruh ciptaan semesta secara fisik. Klausa ini sebagai kelanjutan paralel dengan ayat 7 antara ho tote kosmos dan hoi...nun ouranoi kai he ge-"the heaven and the earth which now exist" menyatakan keadaan langit dan bumi yang sekarang setelah air bah. Richard J. Bauckham menjelaskan bahwa fakta dalam argumentasi ayat 5-7 memerlukan paralel tiga kali lipat yaitu: (l) Allah dalam penciptaan langit dan bumi (2) dia juga yang telah membinasakan langit dan bumi sekali oleh air, (3) dan bahwa dia juga akan menghancurkan sekali lagi oleh api. ${ }^{10}$

Dari kesimpulan tersebut dapat dikatakan bahwa tindakan dan karya Allah dinyatakan hanya oleh firman-Nya. Dengan kata lain bahwa, Allah bersabda maka langit dan bumi menjadi ada, dan sebelum sabda kreatif Allah itu diucapkan semuanya tidak ada. Mazmur 33:6,9 menyatakan bahwa: "oleh firman Tuhan langit dan bumi telah dijadikan... sebab Dia berfirman maka semuanya jadi; Dia memberi perintah maka semuanya ada"(band. Yes. 48:13; Ibr. 11:3).

2. Peristiwa Air Bah

Salah satu pokok penolakan yang dibahas para pengajar sesat adalah penolakan terhadap peristiwa pemusnahan bumi semula oleh air bah. Argumentasi ini, diangkat oleh Petrus dalam suratnya untuk memberi pengertian dan peringatan, untuk menempatkan kepentingan pokok mengenai pemusnahan bumi semula oleh air bah. Bahwa para guru palsu bukan saja tidak mau tahu, tetapi justru dengan sengaja menyatakan bahwa Allah pencipta dan pembuat air bah seolah dengan sengaja telah dilupakan.

Penegasan ini telah jelas dinyatakan dalam 2 Petrus 3:5-6, "mereka sengaja tidak mau tahu, bahwa oleh firman Allah langit telah ada sejak dahulu, dan juga bahwa bumi yang berasal dari air dan oleh air, dan bahwa oleh air itu, bumi yang dahulu, telah binasa dimusnahkan oleh air bah." Buku Introduction to the Bible menguraikan bahwa guru palsu bukan hanya pencetusan rasa permusuhan

${ }^{10}$ Richard J. Bauckham, 2 Peter, Jude: Word Biblical Commentary (Thomas Nelson, 1983), $298-299$. 
melainkan argumetasi-argumentasi yang masuk akal dan didasarkan pada teks-teks Alkitab. ${ }^{11}$

Bumi penuh dengan kejahatan sehingga Tuhan menentukan penghukuman melalui air bah untuk memusnahkan bumi dan segala yang hidup dan bernyawa di bawah kolong langit (Kej. 7:2). Sebuah bahtera yang berbentuk kotak besar yang terapung dan ukurannya dibuat tepat seperti perintah Tuhan yakni: 300 hasta panjangnya, 50 hasta lebar dan 30 hasta tingginya (Kej. 6:15, band 6:22). D. James Kennedy, menguraikan hasil analisa para ilmuwan berdasarkan fakta yang ditemukan berdasarkan keterangan Kejadian 6:15, mengenai kepastian muatan dan daya tampung bahtera Nuh sebagai berikut:

“...panjang kira-kira 450 kaki (kira-kira 150 meter, atau satu setengah kali panjang lapangan sepak bola) kali lebarnya 75 kaki (kira-kira 25 meter) dan kali tingginya 45 kali (kira-kira 15 meter). Karena itu, kapasitasnya adalah lebih dari 1,5 juta kubik kaki (kira-kira 500.000 meter kubik). Untuk memberikan gambaran yang lebih nyata, kapasitas bahtera itu sama dengan 522 gerbong pengangkut hewan kereta api (di Amerika), yang masing-masing bisa memuat 240 ekor domba." ${ }^{2}$

Baxter selanjutnya memberi uraian bahwa: "Tentang adanya banjir besar, menurut pendapat tradisonal yang umum dianut dan menurut penemuan-penemuan ilmu purbakala modern, tidak dapat di sangsikan lagi bahwa suatu banjir besar benar-benar telah terjadi. ${ }^{13}$ Menurut penjelasan Joseph P. Free, bahwa berdasarkan Arkeologi dan Sejarah Alkitab:

“...pengalihan kota Ninewe (1850-1854), menghasilkan lempenglempeng tanah liat yang kemudian terbukti adalah kisah Air Bah menurut versi Babilonia. Dalam banyak hal, kisah ini sangat mirip dengan kisah Alkitab mengenai air bah, dan ini merupakan gambaran yang pasti tentang fakta memang telah terjadi air bah..14

Peritiwa air bah merupakan momentum penting dalam sejarah dunia mengenai perubahan yang telah terjadi. Jadi hal ini tidak dapat dilupakan begitu saja dalam pembahasan argumentasi Petrus

${ }^{11}$ Philip Johnston, IVP Introduction to The Bible Story, Themes and Interpretation (Bandung: Kalam hidup, 2006), 402.

${ }^{12}$ D. James Kennedy, Solving Bible Mysteries: Unraveling the Perplexing and Troubling Passages of Scripture (Nashville, Tennesse: Thomas Nelson, Inc., 2000), 165-166.

13 Sidlow J. Baxter, Menggali Isi Alkitab Roma-Wahyu (Jakarta: Yayasan Komunikasi Bina Kasih, 2009), 29-30.

${ }^{14}$ Joseph P. Free, Arkeologi dan Sejarah Alkitab (Malang: Gandum Mas, 1997), 54. 
terhadap para penyesat. Dalam Kejadian 7 menjelaskan bahwa, hujan lebat telah turun selama 40 hari terus menerus dan meliputi seluruh bumi. Air bah telah menjadi hukuman universal Allah kepada dunia yang fasik dan tidak mau bertobat. Sebab itu Petrus mengacu pada peristiwa air bah untuk menyatakan hukuman pembinasaan dunia akhir zaman yang akan dilakukan dengan api (band. 3 Petrus 3:10).

Pengulangan frasa "oleh air... oleh air" sejajar dengan pernyataan dalam Kejadian 7:11-12, yakni:

"Pada waktu umur Nuh enam ratus tahun, pada bulan yang kedua, pada hari yang ketujuh belas bulan itu, hari itulah terbelah segala mata air samudera raya yang dasyat dan terbukalah tingkap-tingkap langit. Dan turunlah hujan lebat meliputi bumi empat puluh hari empat puluh malam lamanya."

Frasa Alkitab mengenai peristiwa ini sangat jelas dari sudut waktu dan sejarahnya, sehingga tidak dapat dipungkiri oleh siapapun. Bahkan dalam Kejadian 7:21-22 menjelaskan akibat yang terjadi dari bencana air bah tersebut (band. Matius 24:37-39. 1 Petrus 3:20; 2 Petrus 3:5).

Dengan demikian korelasi pernyataan dalam 2 Petrus 3:6, bahwa bumi yang semula telah binasa oleh air bah. Kata Yunani yang dipakai untuk istilah binasa ialah "apoleto". Kata ini oleh Fritz Rienecker, dalam bukunya A Linguistic Key to The Greek New Testament, merupakan kata kerja bentuk aorist, medial, indikatif dari apollumi, yang memiliki arti to ruin, to destroy. ${ }^{15}$ Pengertian ini menunjuk kepada penghancuran hanya oleh Allah sang pencipta. Ungkapan ayat 5, mengenai bumi yang semula "arkaiou kosmos" diterjemahkan sebagai dunia purba, memiliki ekuivalensi dengan kosmos asebôn sebagai dunia bagi orangorang fasik. Kasus yang sama ini akan terjadi sekali lagi pada akhir zaman tetapi pemusnahan dengan api (2 Petrus 3:7).

Karena itu tekanan penghancuran oleh air bah dalam ayat 6 menunjuk kepada penghakiman universal atas dosa manusia, dan bukti penghakiman itu diikut sertakan dengan kehancuran kosmik yang berdampak pada langit dan bumi yang semula. Dengan demikian terjadi perubahan kosmik secara universal. Ham, Snelling dan Wieland, mengatakan jawaban pasti bahwa: "timbulnya air bah pada zaman itu berasal dari sumber air bawah tanah (mata air sumber yang sangat dalam yang terus menerus mengalir selama 150 hari), dan jatuhnya air dari langit (diperkirakan suatu selimut uap air yang besar

${ }^{15}$ Fritz Rienecker and Cleon L. Rogers, A Linguistic Key to The Greek New Testament (Grand Rapids: Zondervan Publishing House, 1984), 289. 
atau semacam atmosfer), menyebabkan 40 hari 40 malam hujan turun."16

Dengan terjadinya peristiwa ini mengakibatkan suatu perubahan struktur tatanan dunia secara total, sehingga menolak konsep pengajaran guru palsu yang menyatakan tidak perubahan sejak semula. Salah satu bukti Alkitab yang menggambarkan perubahan secara total atas dunia ini akibat air bah di ungkapkan dalam Mazmur 140, yang menunjukkan bahwa setelah banjir besar itu, gununggunung menjadi bentuknya seperti sekarang ini, dengan lembah air lautnya yang dalam, yang menampung banjir tersebut, terjadi perubahan struktur bumi pada zaman Peleg sebagai proses membutuhkan benua dan pergeseran bumi (band. Kej. 10:15).

\section{Pendekatan Teologis}

1. Kedatangan Kristus Kedua Kali

Peristiwa kedatangan Kristus berkaitan erat dengan peristiwa pemusnahan bumi sebagai puncak penggenapan janji Tuhan. Karena itu, momentum kedatangan Kristus sangat dinantikan dan menjadi puncak pengharapan orang percaya yang telah diangkat oleh Tuhan bersama Dia.

Peristiwa kedatangan Kristus kedua kali telah dinubuatkan dalam Zakharia 14:1-11 dan Wahyu 19:11-16. Dua aspek yang dapat dikaji dari peristiwa kedatangan Kristus kedua kali, yaitu pertama sebagai waktu pernyataan penghukuman atas dunia dan kedua waktu puncak penyelamatan, sebagaimana yang dinyatakan dalam rangkaian 2 Petrus 3. Peristiwa ini sebagai puncak pernyataan bahwa Allah Maha Kuasa dan berdaulat dalam sejarah dunia, akan mendirikan kerajaan-Nya untuk menggenapi seluruh janji-janji-Nya dalam Alkitab.

Di dalam konteks 2 Petrus 3:4, secara implikasi terkandung pengertian mengenai kedatangan Tuhan Yesus kembali, sebagaimana Kristus kedua kali ini memberikan pengharapan kepada orang percaya, bahwa Allah yang Maha Kuasa yang berdaulat dalam sejarah dunia akan menyertakan penghukuman kepada manusia yang tidak bertobat, tetapi menyelamatkan orang yang mengakui dan percaya kepada Yesus sebagai Tuhan dan Juruselamat pribadi.

2. Langit Baru dan Bumi Baru

"Tetapi sesuai dengan janji-Nya, kita menantikan langit yang baru dan bumi yang baru, dimana terdapat kebenaran (2 Ptr 3:13)."

\footnotetext{
${ }^{16}$ Andrew Snelling, Carl Wieland and Ken Ham. The Answers Book: Answers to the 12 Most-Asked Questions on Genesis and Creation/Evolution (Green Forest: Master Books, 1993), 13.
} 
Penegasan ini menyatakan bahwa Tuhan akan menggantikan langit dan bumi yang akan dimusnahkan oleh api dengan yang baru dan menggantikan juga seluruh tatanan dunia yang sekarang dengan yang baru, sebagaimana uraian mengenai peristiwa pemusnahan bumi dalam bab sebelumnya.

Janji mengenai langit baru dan bumi baru berkaitan dengan nubuatan Yesaya 65:17; 66:22-23, sebagai suatu pemulihan total atas seluruh bumi, dalam peristiwa pemusnahan bumi oleh api (band. Why. 2l:1). Dengan pengertian bahwa langit baru dan bumi baru mencakup nilai kualitas dan kuantitas dari tatanan semesta yang diadakan oleh Tuhan. Sebab air mata akan dihapus, tidak ada lagi maut, tidak ada lagi perkabungan, ratap tangis atau dukacita, sebab segala sesuatu yang lama telah berlalu (Why. 21:4). Demikianlah orang percaya hidup bersama Tuhan Yesus dan menikmati semua berkat yang disiapkan Tuhan selama-lamanya (band. Why. 22:5).

3. Keselamatan atau Hidup Kekal

Petrus mempertegas kehendak Allah bagi keselamatan manusia (2 Petrus 3:9) untuk memberikan hidup kekal bukan sebuah kelalaian. Salah satu kedatangan Yesus kembali setelah mengadakan langit dan bumi baru adalah untuk menggenapi janji-Nya kepada orang percaya tentang kehidupan kekal dalam kerajaan kekal. Hal ini diungkapkan dalam 2 Petrus 3:13, "Tetapi sesuai dengan janji-Nya, kita menantikan langit yang baru dan bumi yang baru, di mana terdapat kebenaran." Frasa di mana terdapat kebenaran berindikasi bahwa kebenaran hanya dapat ditemukan di dalam kerajaan Allah. Inilah yang menjadi puncak pengharapan orang percaya (band. Ladd, 1999:424), sebab itu sejak awal kitab 2 Petrus, rasul Petrus memberi motivasi kepada orang percaya bahwa tujuan akhir dari perjuangan iman Kristen berhubungan dengan pemberian hak untuk ikut masuk ke dalam Kerajaan Tuhan Yesus, seperti yang dikatakannya:

"Karena itu, saudara-saudaraku, berusahalah sungguh-sugguh, supaya panggilan dan pilihanmu makin teguh. Sebab jikalau kamu melakukannya, kamu tidak akan pernah tersandung. Dengan demikian kepada kamu akan dikaruniakan hak penuh untuk memasuki Kerajaan kekal, yaitu kerajaan Tuhan dan Juruslamat kita, Yesus Kristus" (2 Ptr. 1:10-11)

Kerajaan kekal berhubungan dengan pengharapan orang percaya untuk menerima kehidupan kekal, dan bersama dengan Tuhan memerintah sebagai raja sampai selama-lamanya (Why. 22:5). Ini berarti kerajaan kekal tidak hanya didiami oleh Allah dan malaikatmalaikat-Nya, tetapi justru disediakan juga bagi orang-orang dari segala bangsa, suku dan bahasa, yang telah diselamatkan oleh iman di 
dalam Tuhan Yesus. Berdasarkan pada pernyataan firman-Nya demikian 1 Kor. 15:28. Tuhan Yesus telah memberitahukan hal ini kepada manusia melalui khotbah di bukit (Mat. 5:3). Kebahagiaan abadi dijanjikan di dalam kerajaan kekal dalam suasana dan keadaan yang sempurna, "sebab Kerajaan Allah bukanlah soal makanan dan minuman, tetapi soal kebenaran, damai sejahtera dan sukacita oleh Roh Kudus (Rm. 14:17) dan sebab kerajaan Allah bukan terdiri dari perkataan, tetapi dari kuasa.. ${ }^{17}$ Karena itu, Tuhan Yesus menyatakan suatu skala prioritas dalam hidup manusia untuk mengutamakan kerajaan Allah sebagai berikut: "Tetapi carilah dahulu kerajaan Allah dan kebenaran-Nya, maka semuanya itu akan ditambahkan kepadamu." (Matius 6:33).

Sifat dan keadaan kerajaan kekal itu dipenuhi dengan kemuliaan Allah. Kerajaan ini bersifat abadi, sebab tidak ada unsur kefanaan atau yang dapat binasa. Baik itu tempat, waktu maupun penghuninya termasuk orang-orang percaya yang telah dibangkitkan dan telah diubahkan dalam sekejap mata, mengenakan tubuh kemuliaan yang diberikan oleh Tuhan Yesus untuk hidup bersama-Nya untuk selamalamanya (band. 1 Kor. 15:50-56; 1 Tes. 4:16-17).

4. Alkitab Adalah Firman Allah yang Berotoritas

Pengakuan terhadap keberadaan Alkitab adalah firman Allah tanpa salah dalam naskah asli (ineransi Alkitab), (Yunani: pasa grafê theopneuostos), 2 Timotius 3:16 haruslah menjadi landasan presuposisi untuk menghasilkan interprestasi yang benar terhadap Alkitab. Pengakuan ini akan mengantar kepada keyakinan bahwa Alkitab adalah firman Allah yang memiliki otoritas dalam seluruh segmen hidup manusia (band. 2 Timotius 3:16-17).

Petrus menegaskan keyakinan dengan argumentasi bahwa Alkitab adalah firman Allah. Frase, "oleh firman Allah ..."dan lebih tegas lagi dalam 2 Petrus 1:20-2l, yang terutama harus kamu ketahui, ialah bahwa nubuat-nubuat dalam Kitab Suci tidak boleh ditafsirkan menurut kehendak sendiri, sebab tidak pernah nubuat dihasilkan oleh kehendak manusia, tetapi oleh dorongan Roh Kudus orang-orang berbicara atas nama Allah.

Argumentasi ini yang menunjukkan bahwa landasan presuposisi satu-satunya, harus dibangun berdasarkan firman Allah. Landasan presuposisi dikorelasikan dengan argumentasi penciptaan yang telah terjadi oleh firman Allah (band. Kej. 1-2; Mzm. 33:6-9), argumentasi mengenai janji kedatangan-Nya yang kedua, sebagai puncak

${ }^{17}$ Lihat John Walvoord, Penggenapan Nubuatan Masa Kini-Zaman Akhir (Malang: Gandum Mas), 474; R. C. Sproul, Kebenaran-Kebenaran Dasar Iman Kristen (Malang: SAAT Malang, 1997), 369-371. 
penggenapan janji Allah. Seluruh interprestasi yang dibangun harus dapat diuji oleh dan melalui Alkitab. Sebab Alkitab adalah firman Allah yang berotoritas dan bermanfaat dalam hidup dan kegiatan orang percaya (2 Tim. 3:16-17). Semakin mempertegas bahwa Alkitab harus menjadi landasan sumber pengajaran yang benar dan berotoritas, karena seluruh peristiwa sejarah sejak kekekalan masa lampau, situasi dunia sekarang dan sampai pada kekekalan masa depan diuraikan tuntas dalam Alkitab.

\section{Kesimpulan}

Peristiwa eskatologi merupakan pokok teologis yang krusial dalam iman kristen, sebab berbicara mengenai hal-hal akhir dapat memberi motivasi untuk membangun keyakinan iman dan pengharapan akan masa depan. Rangkaian peristiwa eskatologi perlu dipahami dan diletakkan dalam sorotan wahyu Allah yang telah dijanjikan dan digenapinya dalam waktu Tuhan. Selanjutnya sejak abad-abad pertama kehadiran gereja, peringatan Petrus ini telah terjadi seperti telah dinyatakan oleh Yudas dalam tulisannya. Munculnya guru-guru palsu dan pengajaran yang menyesatkan memperkuat alasan pemusnahan bumi oleh api pada waktu Tuhan kedepan menantikan penggenapan janji Allah.

Janji kedatangan Kristus dan peristiwa lainnya di akhir zaman dalam waktu yang dinyatakan Petrus, yang dikutip dalam Mazmur 90, bahwa di hadapan Tuhan satu hari sama seperti seribu tahun dan seribu tahun sama seperti satu hari (2 Ptr. 3:8). Hal ini menegaskan bahwa Allah tidak terikat oleh ruang dan waktu karena Dia adalah pencipta waktu itu. Karena itu, bagi Tuhan waktu kedatangan-Nya itu tidak akan tertangguhkan, namun dalam kesempatan yang ada dalam kaitan dengan program penyelamatan Allah kepada manusia, terlihat seolah-olah ada kelambatan waktu terus terjadi. Supaya dalam waktu kesabaran itu, Allah memberikan kesempatan kepada manusia untuk memperoleh keselamatan dalam Kristus Yesus. Sebab kesegaran janji kedatangan-Nya seperti yang disangkal oleh pengajaran sesat itu pasti terjadi. Bahkan kedatangan-Nya tak terduga seperti pencuri dimalam hari (2 Ptr. 3:10). Dalam awal surat 2 Petrus 3:3, telah diingatkan bahwa harus diketahui pada akhir zaman ini akan tampil pengejek-pengejek dengan ejekan-ejekan yang hanya menurut hawa nafsu dan salah satu ejekannya adalah bahwa janji Tuhan tidak ada dan tidak terjadi perubahan (2 Ptr. 3:4). Dalam tinjauan teologis hari Tuhan mencakup proses waktu yang terjadi waktu gereja berdiri di tengah-tengah dunia hingga pada kedatangan Kristus kedua kali untuk mendirikan kerajaan-Nya di bumi baru. 
Konklusi menyeluruh yang dapat dipahami dari seluruh pembahasan Petrus dalam masa penantian kedatangan Kristus kedua kali dengan berita yang dahsyat, dan penggenapan seluruh program Allah dalam tinjauan teologis, perlu memiliki iman yang tegas seperti nasihat dalam Kolose 1:23, "Sebab itu kamu harus bertekun dalam iman, tetap teguh dan tidak bergoncang, dan jangan mau digeser dari pengarapan Injil yang telah kamu dengar..." korelasi berita tersebut mendorong orang percaya untuk menempatkan Kristus dan janjijanji-Nya sebagai motivasi untuk bertumbuh kearah kehidupan dalam kasih karunia Yesus Kristus sebagaimana yang ditegaskan dalam 2 Petrus 3:1, sebagai peringatan dan memberi pengertian sesuai dengan firman Tuhan, sehingga orang percaya hidup dalam kekudusan dan terus giat dalam pekerjaan Tuhan. Sebab Yesus akan datang kembali dan menjadikan segala sesuatu baru (2 Petrus 3:13 band. Wahyu 21:5).

\section{Kepustakaan}

Bauckham, Richard J. 2 Peter, Jude: Word Biblical Commentary. Thomas Nelson, 1983.

Baxter, Sidlow J. Menggali Isi Alkitab Roma-Wahyu. Jakarta: Yayasan Komunikasi Bina Kasih OFM, 2009.

Berkhof, Hendrikus. Christian Faith, An Introduction to The Study of The Faith. Michigan: Wm. B. Eerdmans Publishing Company, 1975.

Brown, Colin. Filsafat dan Iman Kristen. Jakarta: Lembaga Reformed Injili Indonesia, 1994.

Enoch, Hannington. Evolusi atau Penciptaan. Bandung: Kalam Hidup, 1996.

Ericson, Milard J. Christian Theology. Grand Rapids, Michigan: Baker Book House, 1985.

Free, Joseph P. Arkeologi dan Sejarah Alkitab. Malang: Gandum Mas, 1997.

Gutrie, Donald. Theologia Perjanjian Baru 3. Jakarta: Gunung Mulia, 1999.

Heath, W. Stanley. Sains Iman dan Ilmu Pengetahuan. Yogyakarta: Yayasan ANDI, 1997.

Heath, W. Stanley. Tafsir Kitab Kejadian 1-1l. Yogyakarta: Penerbit ANDI, 1999.

Johnston, Philip. IVP Introduction to The Bible-Story, Themes and Interpretation. Bandung: Kalam hidup. 2006. 
Kennedy, D. James. Solving Bible Mysteries: Unraveling the Perplexing and Troubling Passages of Scripture. Nashville, Tennesse: Thomas Nelson, Inc., 2000.

Rienecker, Fritz dan Cleon L. Rogers. A Linguistic Key to The Greek New Testament. Grand Rapids: Zondervan Publishing House, 1984.

Snelling, Andrew, Carl Wieland dan Ken Ham. The Answers Book: Answers to the 12 Most-Asked Questions on Genesis and Creation/Evolution. Green Forest: Master Books, 1993.

Spence, H. D. M. dan Joseph S. Exell, The Pulpit Bible Commentary Vol. 1 Geresis-Exodus. Peabody, Massachusetts: Hendrickson Publishers, 1996.

Sproul, R. C. Kebenaran-Kebenaran Dasar Iman Kristen. Malang: SAAT Malang, 1997.

Thiessen, Henry C. Teologi Sistematika. Malang: Penerbit Gandum Mas, 1993.

Walvoord, John F. dan Roy B. Zuck. In The Bible Knowledge Commentary: New Testament. Wheaton: Scripture Press Publications, Victor Books, 1984.

Walvoord, John F. Penggenapan Nubuatan Masa Kini-Akhir Zaman. Malang: Gandum Mas, 1996. 


\section{INDEKS}

Indeks Artikel

Baptisan Roh Kudus Berdasarkan Perjanjian Baru

Jermia Djadi

$176-191$

Diutus untuk Menghasilkan Umat yang Kudus: Eksposisi

Yesaya 6:1-13

Peniel C. D. Maiaweng

Doktrin tentang Surga: Relevansinya bagi Tugas Misi Sedunia

Daniel Ronda

$199-212$

Etika dalam Pendidikan: Kajian Etis tentang Krisis Moral

Berdampak Pada Pendidikan

Maidiantius Tanyid.

$235-250$

Implikasi Konsep dan Desain Kurikulum dalam Tugas

Pembinaan Warga Jemaat

Junihot M. Simanjuntak

$251-272$

Konflik Kebudayaan Menurut Teori Lewis Alfred Coser dan

Relevansinya dalam Upacara Pemakaman (Rambu Solo') di

Tana Toraja

Robi Panggarra...

$291-316$

Makna Bait Allah dalam 1 Korintus 3:16-17 dan Implikasi bagi

Orang Percaya Masa Kini

Herman Lesmana dan Robi Panggarra

$128-156$

Pemimpin Sebagai Gembala

Eli Wilson Ipaq

27-34

Penyebab Krisis Identitas Waria

Depilori dan Ivan Th. J. Weismann

$157-175$

Peran Gembala Jemaat terhadap Pengembangan Pelayanan

Holistik di Gereja Kemah Injil Indonesia Jemaat Yegar Sahaduta

Jayapura

Reinhard Jeffray Berhitu

$273-290$

Sejarah Pendidikan Sekolah Kristen Gereja Toraja Suatu

Kajian Historis Kritis Tentang Peran Gereja Toraja

Melaksanakan Pendidikan Sekolah Kristen Dari Masa Zending

Sampai Masa Reformasi

Yan Malino dan Daniel Ronda

$35-70$

Studi Biblika dan Teologis Surat 2 Petrus Pasal 3

Eliezer Lewis.

$317-332$

The Implementation of Incarnational Mission Among The

Bugis Using Cultural Approach

Armin Sukri

$93-127$

Tinjauan Teologis tentang Mimpi Berdasarkan Kitab

Kejadian 37:1-ll dan Relevansinya dalam Kehidupan Orang 
Percaya Masa Kini

Fini Ardila

Turut Membina Indonesia Sebagai Rumah Bersama - Peran

Gereja Dalam Politik Di Indonesia

Zakaria J. Ngelow

\section{Indeks Penulis}

Berhitu, Reinhard Jeffray. Peran Gembala Jemaat terhadap

Pengembangan Pelayanan Holistik di Gereja Kemah Injil Indonesia

Jemaat Yegar Sahaduta Jayapura.

273-290

Depilori dan Ivan Th. J. Weismann. Penyebab Krisis Identitas

Waria

Djadi, Jermia. Baptisan Roh Kudus Berdasarkan Perjanjian Baru ...

$176-191$

Fini Ardila. Tinjauan Teologis tentang Mimpi Berdasarkan Kitab

Kejadian 37:1-11 dan Relevansinya dalam Kehidupan Orang

Percaya Masa Kini

Ipaq, Eli Wilson. Pemimpin Sebagai Gembala.

Lesmana, Herman dan Robi Panggarra. Makna Bait Allah dalam 1 Korintus 3:16-17 dan Implikasi bagi Orang Percaya Masa Kini

$128-156$

Lewis, Eliezer. Studi Biblika dan Teologis Surat 2 Petrus Pasal 3.....

Maiaweng, Peniel C. D.. Diutus untuk Menghasilkan Umat yang

Kudus: Eksposisi Yesaya 6:1-13

$317-332$

$1-26$

Malino, Yan dan Daniel Ronda. Sejarah Pendidikan Sekolah

Kristen Gereja Toraja Suatu Kajian Historis Kritis Tentang Peran Gereja Toraja Melaksanakan Pendidikan Sekolah Kristen

Dari Masa Zending Sampai Masa Reformasi

Ngelow, Zakaria J.. Turut Membina Indonesia Sebagai Rumah Bersama - Peran Gereja Dalam Politik Di Indonesia ......

Panggarra, Robi. Konflik Kebudayaan Menurut Teori Lewis Alfred Coser dan Relevansinya dalam Upacara Pemakaman (Rambu Solo') di Tana Toraja

Ronda, Daniel. Doktrin tentang Surga: Relevansinya bagi Tugas Misi Sedunia

Simanjuntak, Junihot M. Implikasi Konsep dan Desain Kurikulum dalam Tugas Pembinaan Warga Jemaat

Sukri, Armin. The Implementation of Incarnational Mission Among The Bugis Using Cultural Approach

Tanyid, Maidiantius. Etika dalam Pendidikan: Kajian Etis tentang Krisis Moral Berdampak Pada Pendidikan 